\title{
SHAKEDOWN OF COMPOSITE FRAMES TAKING INTO ACCOUNT PLASTIC AND BRITTLE FRACTURE OF ELEMENTS
}

\author{
Piotr ALAWDIN ${ }^{1,1}$, George BULANOV ${ }^{2}$ \\ ${ }^{1}$ University of Zielona Góra, Institute of Building Engineering, Poland \\ ${ }^{2}$ RUP "Instytut BelNIIS", Minsk, Belarus
}

\begin{abstract}
In the paper the mathematical model of the optimization problem of limit and shakedown analysis for composite plane frames, containing elastic-plastic and brittle elements under low-cyclic loading, is proposed. It is assumed that the load varies randomly within the specified domain, and limited plastic redistribution of forces in such structures occurs. An example of the shakedown analyses of the composite frame is given.
\end{abstract}

Keywords: limit and shakedown analysis, composite plane frames, elastic-plastic and brittle elements

\section{INTRODUCTION}

Composite construction systems combine benefits of concrete stiffness with high steel resistance and speed of steel erection. These systems are recommended to be used in high-rise buildings [1] and highly loaded constructions, such as skyscrapers, industrial structures etc. Typically, in composite constructions the erection of steel frame advances to a predetermined height using steel erection columns, which are then encased in reinforced concrete as shown in Fig. 1.

The paper presents a method for determining the mechanisms of brittle-plastic destruction of composite concrete building frames, which can be used in assessing stress state of the composite frame in post-elastic stage.

\footnotetext{
${ }^{1}$ Corresponding author: University of Zielona Gora, Institute of Building Engineering,
} Szafrana st 1, 65-516 Zielona Gora, Poland, e-mail: p.aliawdin@ib.uz.zgora.pl, tel.+48683282322 
Such assessment is required for: designing the structures to resist an earthquake [2-3], progressive collapse analysis [4], as well as for choosing strategies for the protection of buildings against accidents[5]. Effective seismic protection systems often include various combinations of plastic and brittle elements [6], which absorb energy of external actions. Limited analysis of the elastic-plastic system has been studied in many papers (see, for example [7, 8, 18, 19]). At the same time, the important issues connected with the presence of brittle elements in the structures were discussed significantly less [20].



Fig. 1. General construction sequence in composite structures

In this paper, which is based on the approach proposed by the first author [8],we consider plastic and brittle fracture of elements and formulate optimization problem of limit analysis and shakedown of plane rod systems in composite frame of buildings. It is assumed that the load varies randomly within the specified limits.

In the columns and beams of buildings we propose a possibility of appearance of a plastic hinge with elastic-plastic fracture (against the action of the bending moment and the normal force), and the possibility of the brittle fracture of the elements (against the action of shear force). As a result of solving the optimization problem we have defined the mechanism of fracture of the reinforced concrete frame, the most unfavorable load parameters and the residual stresses in the plastic elements. An example of shakedown analyses of composite concrete frame with elastic-plastic and elastic-brittle elements is presented. 


\section{MATHEMATICAL MODEL OF OPTIMIZATION PROBLEM}

An "elastic" solution of equation (1) is used then as the basis for the analysis of inelastic system. Namely the problem of load-bearing capacity of structures made of perfectly elastic-plastic and elastic-brittle elements under variable loads is formulated as follows: to find the vectors of single loadings $\boldsymbol{F}_{j}, j \in J$, a parameter (safety factor) $\mu$ for load $\boldsymbol{F}$, as well as the vector of residual forces $\boldsymbol{S}^{r}$ $=\left(\boldsymbol{S}_{p l}{ }^{r}, \boldsymbol{S}_{b r}{ }^{r}\right)$ such, that

$$
\begin{gathered}
\mu \rightarrow \max , \\
\mathbf{S}^{\mathrm{e}}(\mathrm{t})=\boldsymbol{\omega}_{\mathrm{SF}} \mu \mathbf{F}, \\
\mathbf{S}^{\mathrm{e}}(\mathrm{t})=\left(\mathbf{S}_{\mathrm{pl}}{ }^{\mathrm{e}}, \mathbf{S}_{\mathrm{br}}{ }^{\mathrm{e}}\right), \\
\mathbf{A}_{\mathrm{pl}} \mathbf{S}_{\mathrm{pl}}{ }^{\mathrm{r}}=\mathbf{0}, \\
\boldsymbol{\varphi}_{\mathrm{pl}}\left(\mathbf{S}_{\mathrm{pl}}{ }^{\mathrm{e}}+\mathbf{S}_{\mathrm{pl}}{ }^{\mathrm{r}}, \mathbf{S}_{0, \mathrm{pl}}\right) \leq \mathbf{0}, \\
\max _{i \in I_{b r}} \boldsymbol{\varphi}_{\mathrm{br}}\left(\mathbf{S}_{\mathrm{br}}{ }^{\mathrm{e}}, \mathbf{S}_{0, \mathrm{br}}\right)_{\mathrm{i}} \leq \mathbf{0}, \\
\mathbf{F}(\mathrm{t}) \in \Omega\left(\mathbf{F}_{\mathbf{j}}, \mathrm{j} \in \mathrm{J}\right),
\end{gathered}
$$

where $\boldsymbol{\omega}_{S \boldsymbol{F}}$ is the influence matrix of the load vector $\boldsymbol{F}$ on the force vector $\boldsymbol{S}^{e}, \boldsymbol{S}^{e}=\left(\boldsymbol{S}_{p l}{ }^{e}, \boldsymbol{S}_{b r}{ }^{e}\right)$;

$\boldsymbol{S}_{p l}{ }^{e}$ и $\boldsymbol{S}_{b r}{ }^{e}$ are the force vectors in sections of the elastic-plastic and elastic-brittle elements in the elastic range of work respectively;

$\boldsymbol{A}_{p l}$ is the matrix of equilibrium equations of the residual forces $\boldsymbol{S}_{p l}{ }^{r}$ in the sections of the elastic-plastic elements;

$\boldsymbol{S}^{e}, \boldsymbol{S}^{r}$ are the vectors of elastic and residual forces in the sections of the elements;

$\boldsymbol{F}_{j}$ is the vectors of $j$-th combinations of loads, $j \in J$,

$J$ is the array of the loads combinations;

$I_{b r}$ is the array of the $i$-th brittle elements;

$\Omega(\bullet)$ is the array of the loads $\boldsymbol{F}$. 
Here $\boldsymbol{\varphi}_{p / \Omega F}$ are the yield functions, depending on the set $\Omega_{F}$ external actions (loads $\boldsymbol{F}_{j}$ ) for elastic-plastic elements; $\boldsymbol{\varphi}_{b r}$ are the strength functions for brittle elements; $\boldsymbol{\omega}_{F}, \boldsymbol{\omega}_{\boldsymbol{d}}$ is the matrix of loads influence on the elastic forces; $\boldsymbol{A}_{p l}$ is a matrix of equilibrium equations (2.4). The subscripts $p l$ and $b r$ relate to the elastic-plastic and elastic-brittle elements, superscripts $e$ and $r$ relate to the elastic and residual forces.

The equations (2.1)-(2.7) are a problem of nonlinear programming (NLP).

After finding the failure mechanism (active constraints $(2.5,2.6)$ ) in problem (2.1)-(2.7) one must take into account the dynamic effects of this destruction in iterative procedure [10]. The simple approach to such dynamic analysis was proposed in [11].

Note that the problem for mixed structures with elastic-plastic and elastic-brittle elements, formulated above, is new. In this problem in addition to loads $\boldsymbol{F}_{j}$ it is possible to consider the dislocations $\boldsymbol{d}_{j}$ as similar external actions. By changing the dislocation $\boldsymbol{d}_{j}$ we can also optimize the state of structures pretesting.

In the particular case of one-pass loading the problem (2.1)-(2.7) is simplified [9], while $|J|=1$, this problem is also applicable for the analysis of the progressive destruction of structures [12].

\section{EXAMPLE OF SHAKEDOWN ANALYSES OF COMPOSITE FRAME}

An example of shakedown analyses of composite concrete frame with elasticplastic and elastic-brittle elements (Fig. 2) is given below.

Two types of the load are acting on this frame: 1) dead load (Fig. 3a); 2) life load as a horizontal load applied to each floor and acting alternately in opposite directions (Figure 3b). These loads are included in two load combinations.

FEA software SAP2000 is used for calculation in elastic stage. Design model with joints and members labels is shown in Fig. 3. The cross-sections of the frame elements are shown in Table 1. Strength class for concrete C35/45 is used.

According to [13] full shear connection was provided between the structural steel section and the web encasement. 


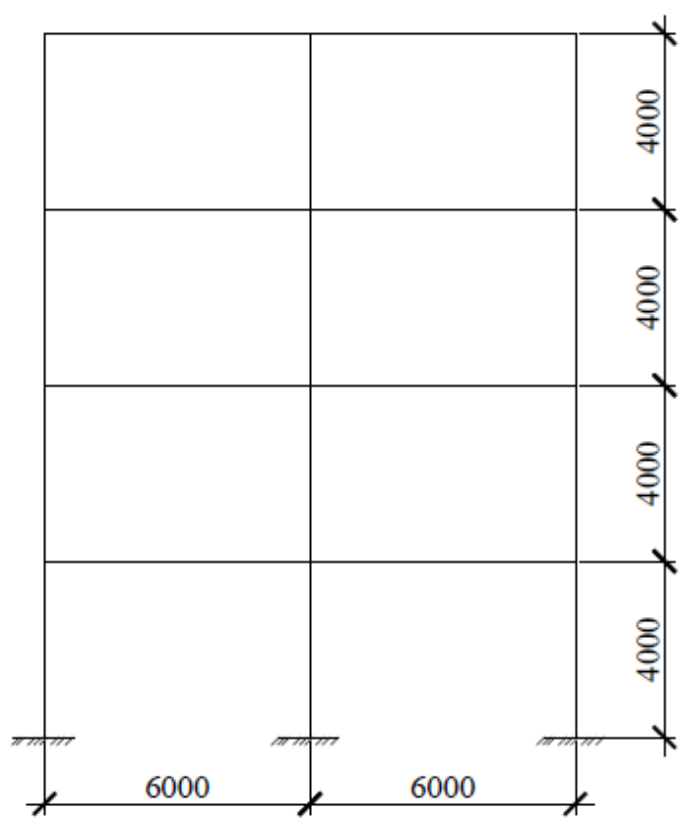

Fig. 2. Composite concrete frame

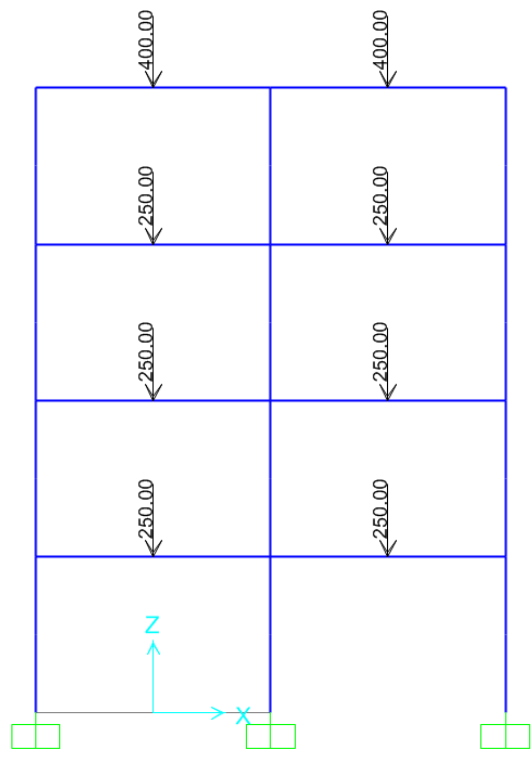

a)

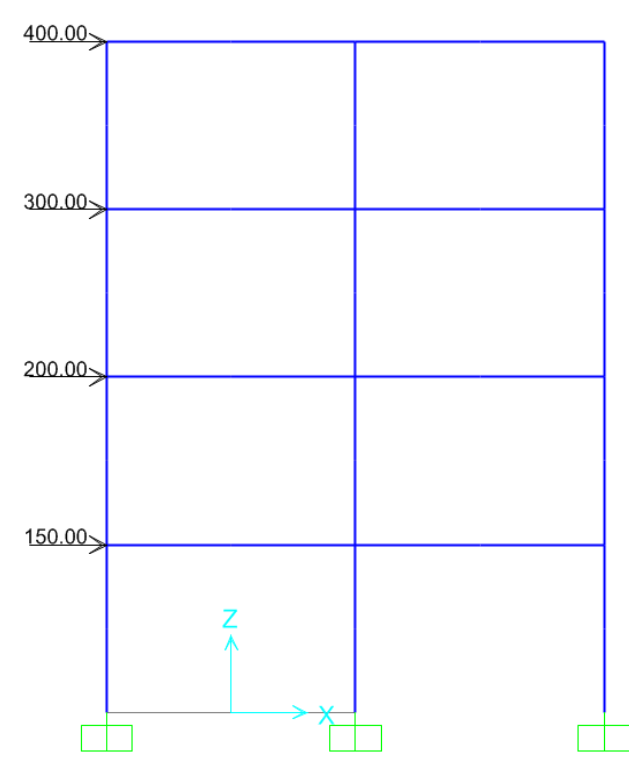

b)

Fig. 3. Loads acting on frame, $k N$ 


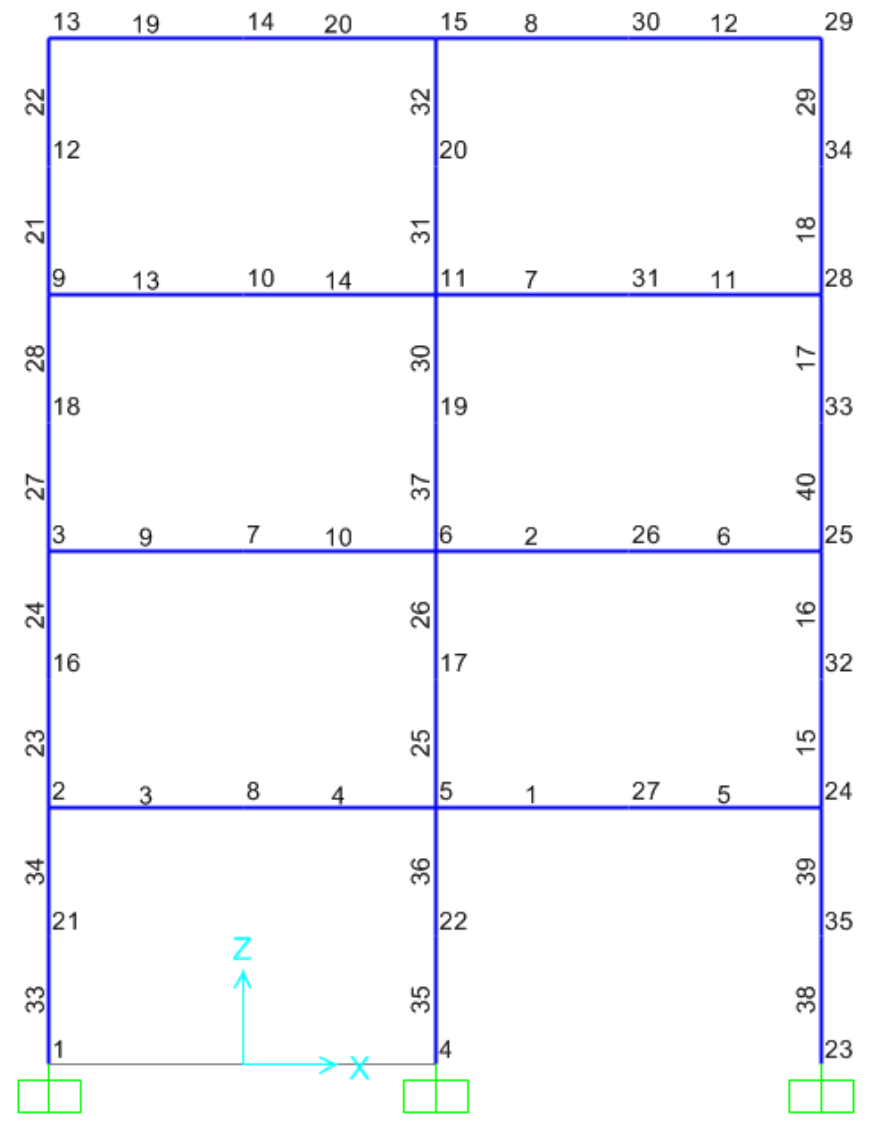

Fig. 4. Design model of frame

Table 1. Sections of frame members

\begin{tabular}{|c|c|c|c|c|c|c|c|c|c|}
\hline \multirow[t]{2}{*}{ № } & & \multirow[t]{2}{*}{ Section } & \multicolumn{2}{|c|}{$\mathrm{b}, \mathrm{MM}$} & \multirow{2}{*}{$\begin{array}{c}\mathrm{H}, \\
\mathrm{mm}\end{array}$} & \multicolumn{2}{|c|}{$\begin{array}{l}\text { Longitudinal } \\
\text { reinforcement, } \\
\text { class }\end{array}$} & \multirow[t]{2}{*}{$\begin{array}{l}\text { Steel } \\
\text { section, } \\
\text { class }\end{array}$} & \multirow[t]{2}{*}{$\begin{array}{l}\text { Member } \\
\text { labels in } \\
\text { model }\end{array}$} \\
\hline & & & top & bottom & & top & $\begin{array}{c}\text { botto } \\
\mathrm{m}\end{array}$ & & \\
\hline 1 & : : : & $:::::$ : $:$ & 1000 & 300 & 600 & $\begin{array}{l}3 \varnothing 20, \\
\text { B500B }\end{array}$ & $\begin{array}{l}\varnothing 12, \\
\text { В500B }\end{array}$ & $\begin{array}{l}\text { HE400A } \\
\text { S275 }\end{array}$ & $\begin{array}{l}2,6,7,8,9, \\
10,11,12, \\
13,14,19, \\
20\end{array}$ \\
\hline
\end{tabular}





Fig. 5. Moment-curvature curve

The plastic moment capacity of all composite concrete members was calculated by moment-rotation (curvature) analyses based on mean value of material properties. The moment-rotation curve can be idealized with an elastic perfectly plastic response to estimate the plastic moment capacity of a member's crosssection [14]. The elastic portion of the idealized curved should pass through the point marking the first reinforcing bar yield. The idealized plastic moment capacity is obtained by balancing the areas between the actual and the idealized moment-rotation curves beyond the first reinforcing bar yield point, see Fig. 4. The idealized moment-curvature curves for members' cross-sections have shown in Table 2 and 3. 
Table 2. The idealized moment-curvature curves for columns' cross-sections

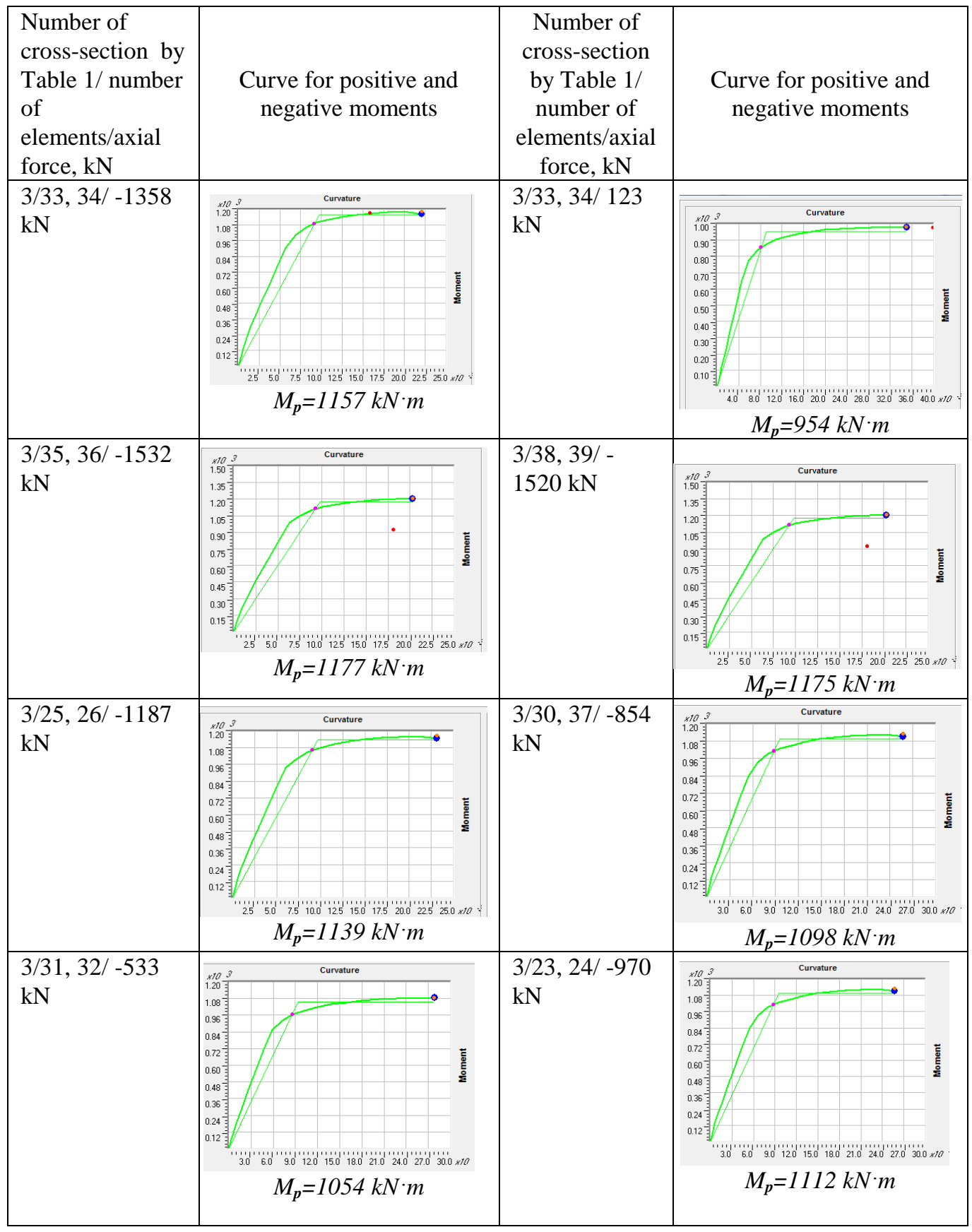


SHAKEDOWN OF COMPOSITE FRAMES TAKING INTO ACCOUNT PLASTIC AND 13 BRITTLE FRACTURE OF ELEMENTS

\begin{tabular}{|l|c|l|c|}
\hline $3 / 23,24 /-33 \mathrm{kN}$ & $M_{p}=980 \mathrm{kN} \cdot \mathrm{m}$ & $\begin{array}{l}3 / 27,28 /-596 \\
\mathrm{kN}\end{array}$ & $M_{p}=1064 \mathrm{kN} \cdot \mathrm{m}$ \\
\hline $3 / 27,28 /-128$ & $M_{p}=993 \mathrm{kN} \cdot \mathrm{m}$ & $\begin{array}{l}3 / 21,22 /-279 \\
\mathrm{kN}\end{array}$ & $M_{p}=1012 \mathrm{kN} \cdot \mathrm{m}$ \\
$\mathrm{kN}$ & $M_{p}=995 \mathrm{kN} \cdot \mathrm{m}$ & $\begin{array}{l}3 / 15,16 /- \\
1073 \mathrm{kN}\end{array}$ & $M_{p}=1125 \mathrm{kN} \cdot \mathrm{m}$ \\
\hline $3 / 21,22,15,16$ & $M_{p}=1070 \mathrm{kN} \cdot \mathrm{m}$ & $3 / 40,17 /-181$ & $M_{p}=998 \mathrm{kN} \cdot \mathrm{m}$ \\
$/-138 \mathrm{kN}$ & & $\mathrm{kN}$ & \\
\hline $3 / 40,17 /-647$ & $M_{p}=1014 \mathrm{kN} \cdot \mathrm{m}$ & $\begin{array}{l}3 / 18,29 /-153 \\
\mathrm{kN}\end{array}$ & \\
\hline $3 / 18,29 /-294$ & & $M_{p}=996 \mathrm{kN} \cdot \mathrm{m}$ \\
$\mathrm{kN}$ & &
\end{tabular}

Table 3. The idealized moment-curvature curves for beams' cross-sections






\begin{tabular}{|l|c|c|}
\hline $\mathrm{kN}$ & & \\
\hline $1 / 13,14 / 205$ & $M_{p}=1049 \mathrm{kN} \cdot \mathrm{m}$ & $M_{p}=890 \mathrm{kN} \cdot \mathrm{m}$ \\
$\mathrm{kN}$ & $M_{p}=1090 \mathrm{kN} \cdot \mathrm{m}$ & $M_{p}=953 \mathrm{kN} \cdot \mathrm{m}$ \\
\hline $1 / 7,11 /-52$ & $M_{p}=1068 \mathrm{kN} \cdot \mathrm{m}$ & $M_{p}=917 \mathrm{kN} \cdot \mathrm{m}$ \\
$\mathrm{kN}$ & & \\
\hline $1 / 7,11 / 103$ & $\mathrm{kN}$ & \\
\hline
\end{tabular}

Transverse reinforcement of all frame elements is made of bars $\emptyset 8 \mathrm{~B} 500 \mathrm{~B}$, at $200 \mathrm{~mm}$. Resistance to vertical shear designed in accordance with [13]. The distribution of the total vertical shear $V_{\mathrm{Ed}}$ into the parts $V_{\mathrm{a}, \mathrm{Ed}}$ and $V_{\mathrm{c} \text {,Ed, }}$ acting on the steel section and the reinforced concrete web encasement respectively assumed to be in the same ratio as the contributions of the steel section and the reinforced web encasement to the bending resistance $M_{\mathrm{pl}, \mathrm{Rd}}$.

Envelope elastic bending moment diagram is shown in Fig. 6.

To solve the optimization problem first of all we have to find the residual forces vector $\boldsymbol{S}_{p l}{ }^{r}$ in the sections of the elastic-plastic elements. This frame is 24 times statically indeterminate. Taking into account that the brittle links do not allow plastic redistribution, there are only 8 links through moments in which the system can adapt to external action remains. Thus $\boldsymbol{S}_{p l}{ }^{r}=\boldsymbol{\omega}_{X} \boldsymbol{X}$, where $\boldsymbol{\omega}_{X}$ is a influence matrix of independent residual forces vector $\boldsymbol{X} \in \boldsymbol{R}^{8}$ on the vector $\boldsymbol{S}_{p l}{ }^{r}$. Single residual moment diagrams from the components of residual forces of unit vector $\bar{X}=(1, \ldots, 1) \in \boldsymbol{R}^{8}$ in the basic system are shown in Fig.7.

Then the nonlinear optimization problem was solved as a sequence of linear programming ones. For the first iteration the safety factor for load $\mu=1,175$ was obtained for the vector of independent residual forces $\boldsymbol{X}=(-226.48$, $-136.55,134.97,0,-324.08,-228.17,48.41,331.82)$. Interaction between the moment capacity and the axial force was taken into account for the second iteration and the safety factor for load $\mu=1,173$ was obtained for the vector of independent residual forces $\boldsymbol{X}=(-217.81,-157,92.72,0,-315.27,-248.5,43.7$, 310.7). Envelope elastic moments diagram considering the safety factor for load is shown in Fig. 8 and the envelope moments diagram considering limited plastic redistribution of internal forces is exposed in Fig. 9. 

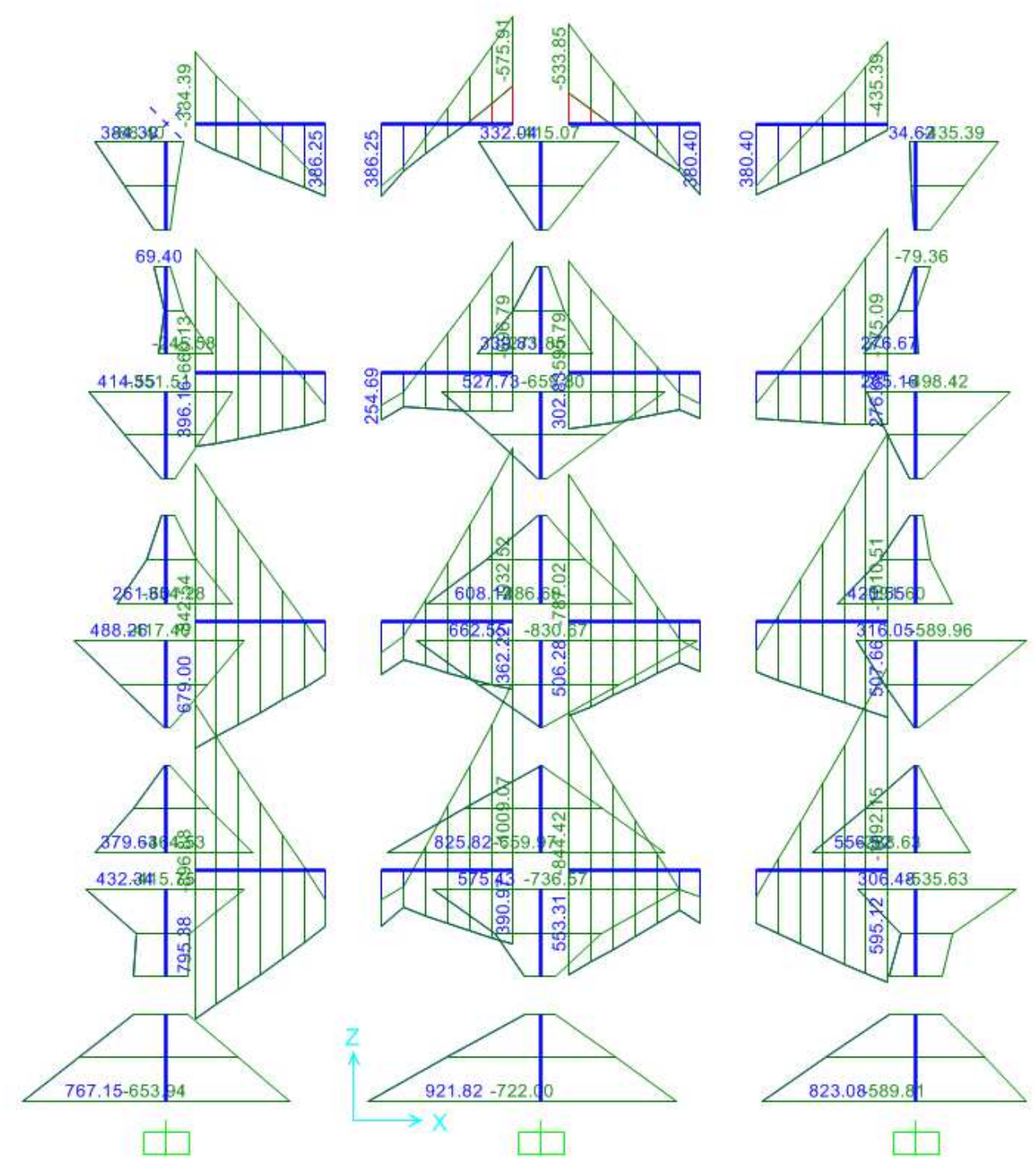

Fig. 6. Envelope bending moment diagram, $k N \cdot \mathrm{m}$ 


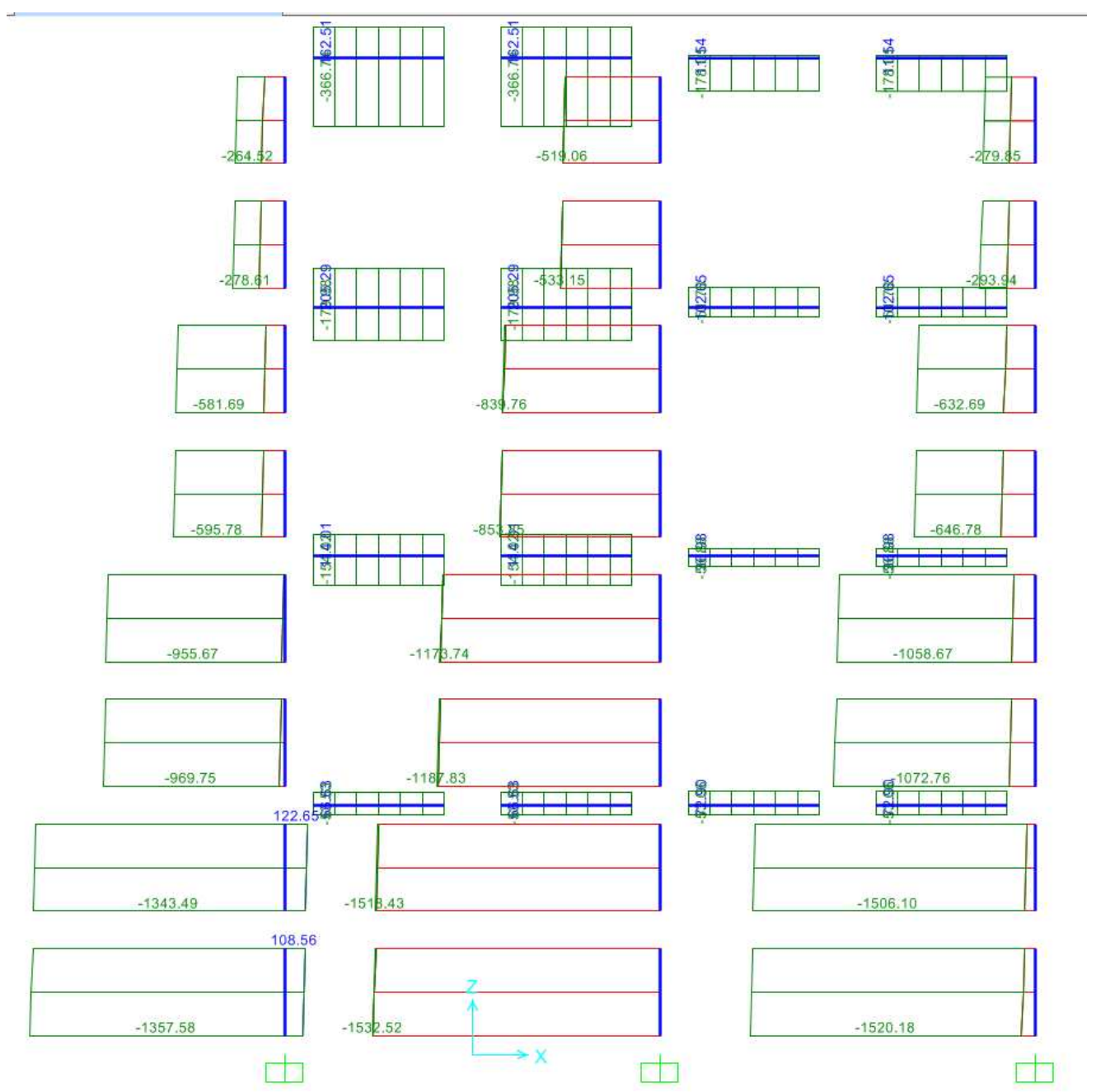

Fig. 7. Envelope axial forces diagram, $k N$ 


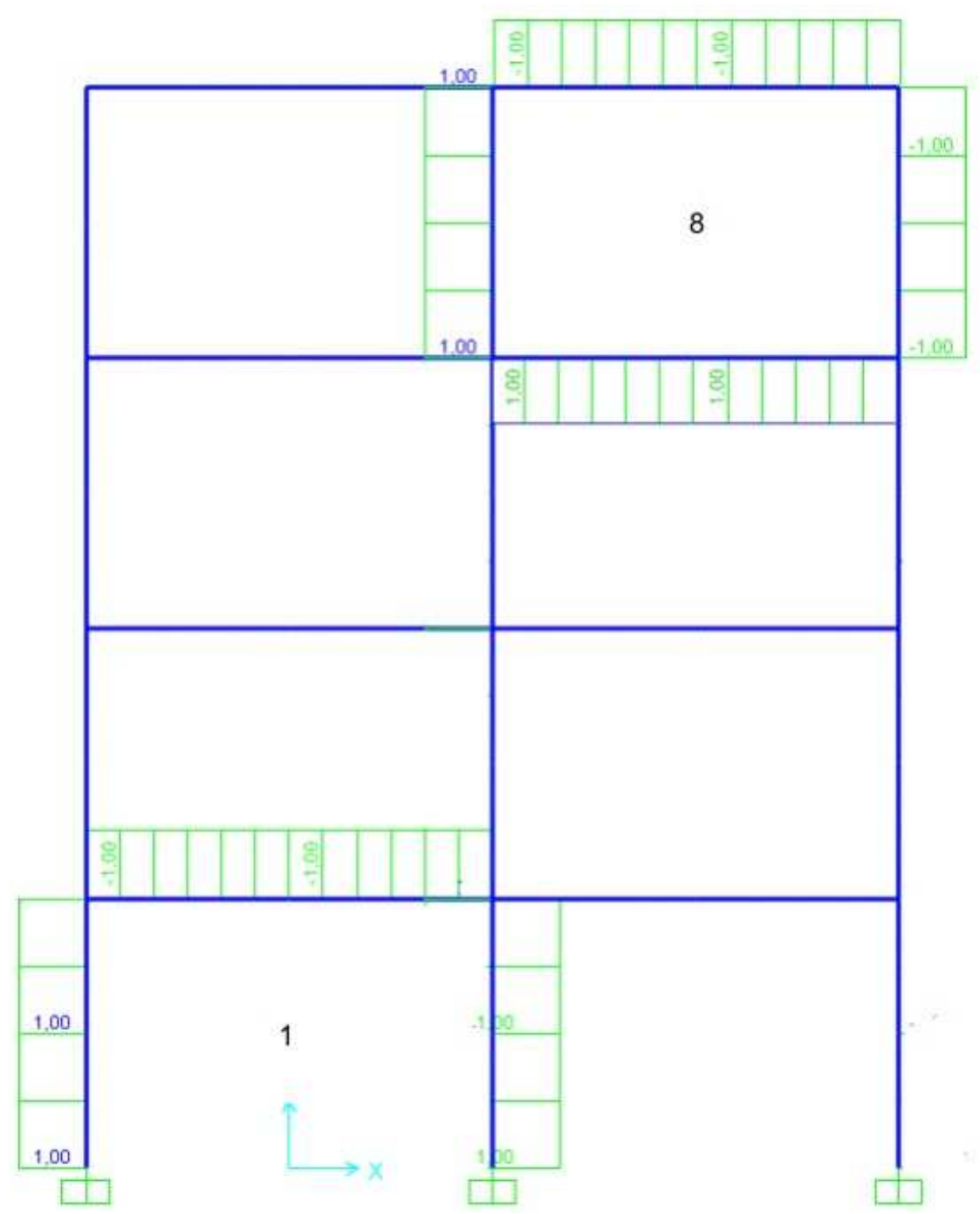

Fig. 8. Unit residual $i$-th moment diagrams, $i=1, \ldots, 8$ 

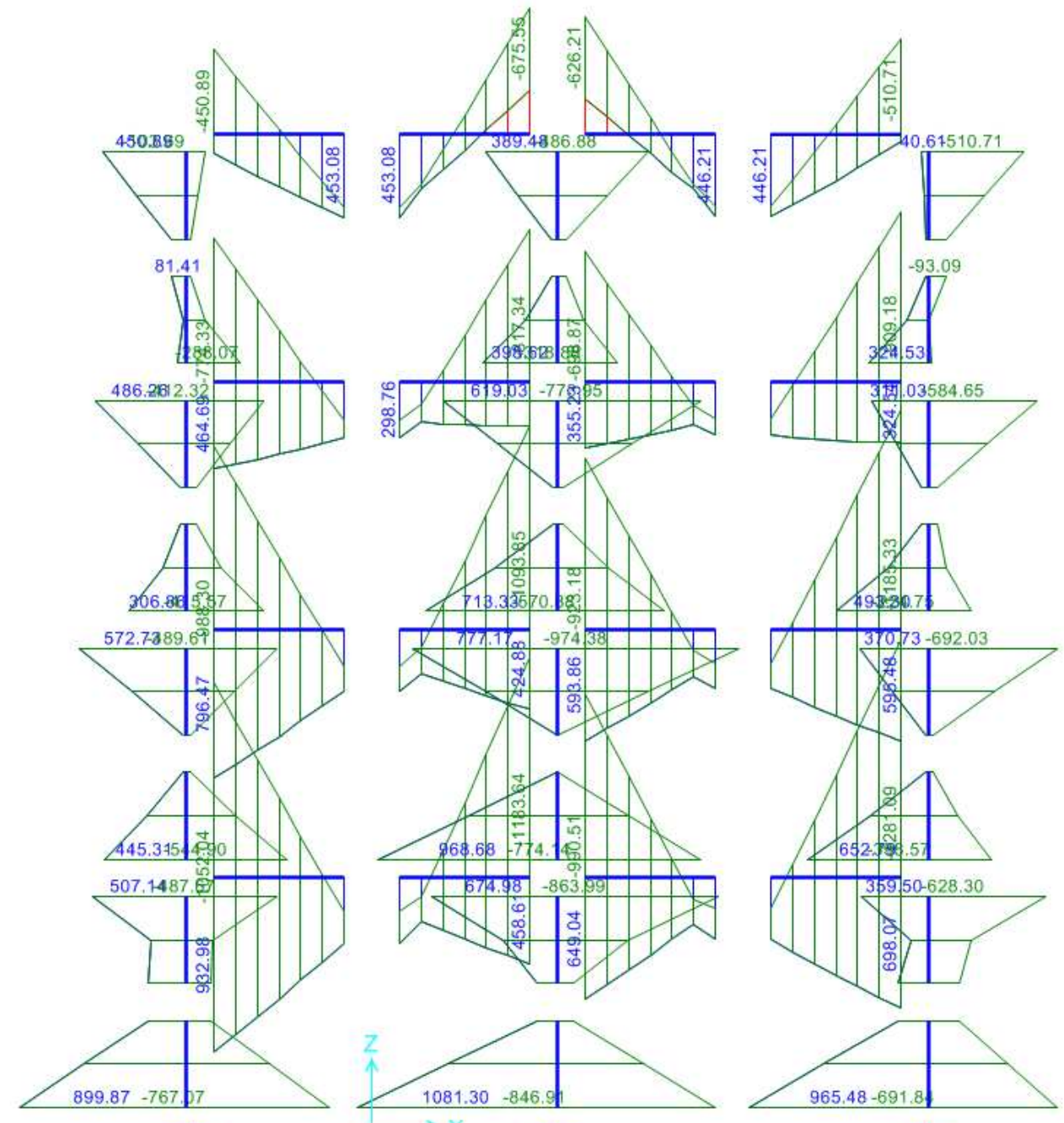

Fig. 9. Envelope elastic moments diagram (increased by the safety factor), $k N \cdot m$ 


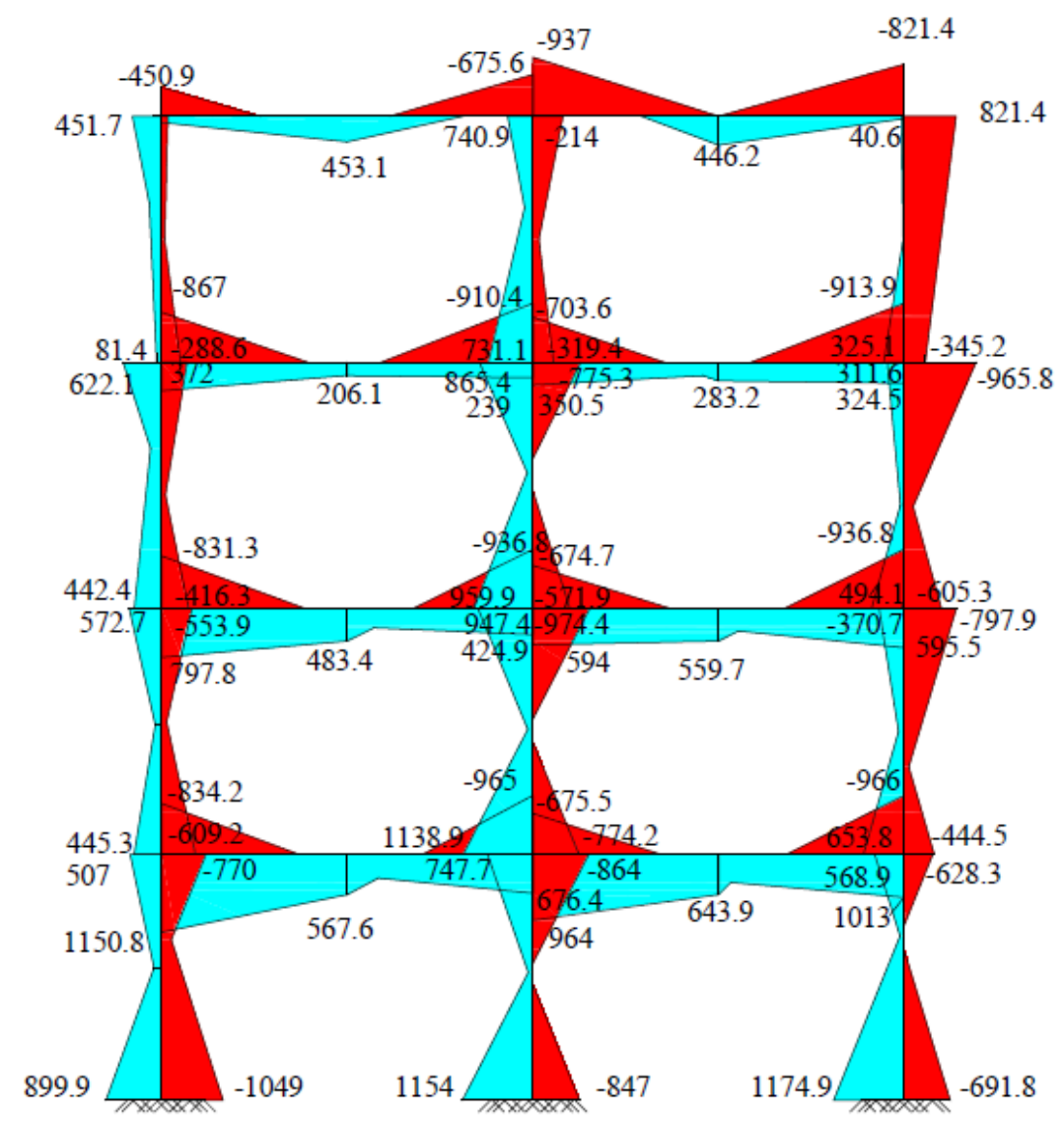

Fig. 10. Envelope moments diagram after limited plastic redistribution of forces, $\mathrm{kN} \cdot \mathrm{m}$

\section{CONCLUSIONS}

The paper presents a mathematical model of optimization problem for shakedown analysis of the composite plane frames under low-cyclic loading. For such structures in addition to plastic, there also appears a brittle failure of the elements against lateral forces. Existing simplified methods cannot account for the joint work of the steel section and concrete grouting under shear. Due to the possibility of limited plastic redistribution of forces in the structure the proposed analysis can recognize additional reserve of bearing capacity for this 
composite frames, at the same time taking into account the brittle and ductile elements. Identification of load bearing capacity reserve is especially important in the structures design for special actions.

\section{REFERENCES}

1. Bungale S. Taranath: Structural Analysis and Design of Tall Buildings. Steel and Composite Construction, Boca Raton, Taylor \& Francis Group, 2012.

2. Eurocode 8: Design of structures for earthquake resistance. Part 1: General rules, seismic actions and rules for buildings, Brussels, European Committe for standardizations, 2004.

3. Eurocode 8: Design of structures for earthquake resistance. Part 3: Assessment and retrofitting of buildings, Brussels, European Committe for standardizations, 2005.

4. James C. Dalton: Design of buildings to resist progressive collapse / James C. Dalton, P.E. [et al.], USA, 2010.

5. Eurocode 1: Actions on structures. Part 1-7: General actions - Accidental actions, Brussels, European Committe for standardizations, 2006.

6. Minasian A.V.: Bearing capacity reserves of seismic-protected systems in terms of energy viewpoint, in: Actual problems of research on the theory of structures: Proceedings of the International Conference, (Vol. 1), Moscow, V.A. Kucherenko TSNIISK, 2009, 270-276.

7. Čyras A., Borkowski A., Karkauskas R.: Theory and methods of optimization of rigid-plastic systems / Vilnius: Technika, 2004.

8. Aliawdin P.W.: Limit analysis of structures under variable loads, Mińsk: UP «Technoprint», 2005. (In Russian).

9. Alawdin P.W., Bulanov G.V.: Analysis of RC frames taking in account plastic and brittle fracture of elements, in: Problems of modern concrete and reinforced concrete. Minsk: StrojMediaProekt, 2013, 13-26. (In Russian).

10. Alyavdin P.: Shakedown analysis of effective bearing structures with unsafe members under dynamic loading, in: Modern Building Materials, Structures and Techniques: Proceedings of the 5th International Conference, (Vol. II), Vilnius, Technica, 1997, 167-172.

11. Geniev G.A., Kolchunov V.I., Klyueva N.V., Nikulin, A.I., Pyatikrestovsky K.P.: The strength and deformability of reinforced concrete structures under over-design influences / Moscow, Izd-vo of Association of Building Universities, 2004.

12. Ellingwood B.R., et al.: Best Practices for Reducing the Potential for Progressive Collapse in Buildings, National Institute of Standards and 
Technology, Technology Administration, U.S. Department of Commerce, 2006.

13. Eurocode 4: Design of composite steel and concrete structures for. Part 11: General rules and rules for buildings, Brussels, European Committe for standardizations 2005.

14. Caltrans Seismic Design Criteria, Version 1.7, Caltrans, 2013.

15. CSI Analysis Reference Manual For SAP2000, ETABS, SAFE and CSiBridge, USA, Berkley, Computers and Structures, Inc., 2011.

16. Dem'anov V.F., Stavroulakis G.E., Polyakova L.N., Panagiotopoulos P.D.: Quasidifferentiability and Nonsmooth Modelling in Mechanics, Engineering and Economics / Nonconvex Optimization and Its Applications, (Vol. 10), Kluwer Academic Publishers, Dordecht/Boston/London, 1996.

17. Atkočiūnas J.: Optimal shakedown design of elastic-plastic structures. Vilnius: Technika, 2011.

18. Structures Subjected to Repeated Loading: Stability and strength, Eds. R. Narayanan, T.M.Roberts, London and New York: Elsevier, 1991.

19. Nielsen M. P., Hoang L. C.: Limit Analysis and Concrete Plasticity - 3rd ed., Boca Raton, London, New York: CRC Press, Taylor \& Francis Group, 2011.

20. Banichuk N.V., Neittaanmäki Pekka: Structural Optimization with Uncertainties (Solid Mechanics and Its Applications), Dordrecht, Heidelberg, London, New York: Springer, 2010.

\section{PRZYSTOSOWANIE RAM ZESPOLONYCH Z UWZGLĘDNIENIEM PLASTYCZNEGO I KRUCHEGO ZNISZCZENIA ELEMENTÓW}

\section{Streszczenie}

W pracy przedstawiono model matematyczny optymalizacji nośności granicznej i przystosowania płaskich ram zespolonych stalowo-betonowych, zawierających sprężysto-plastyczne i kruche elementy. Przyjęto, że obciążenie zmienia się w dowolny sposób w określonym obszarze. W takich konstrukcjach po obciążeniu niskocyklowym występuje ograniczone plastyczne wyrównanie sił wewnętrznych. Podano przykład analizy przystosowania ramy zespolonej.

Słowa kluczowe: ramy zespolone, element sprężysto-plastyczne I kruche, obciążenia zmienne 